DOI: 10.25178/nit.2019.1.6

\title{
Мир визуальных образов старообрядцев Тувы: от иконы и лубочной картинки до фотографии"
}

\author{
Екатерина В. Быкова
}

Вятский государственный университет, Российская Федерация,

\section{Александр А. Пригарин}

Одесский национальный университет им. И. И. Мечникова, Украина
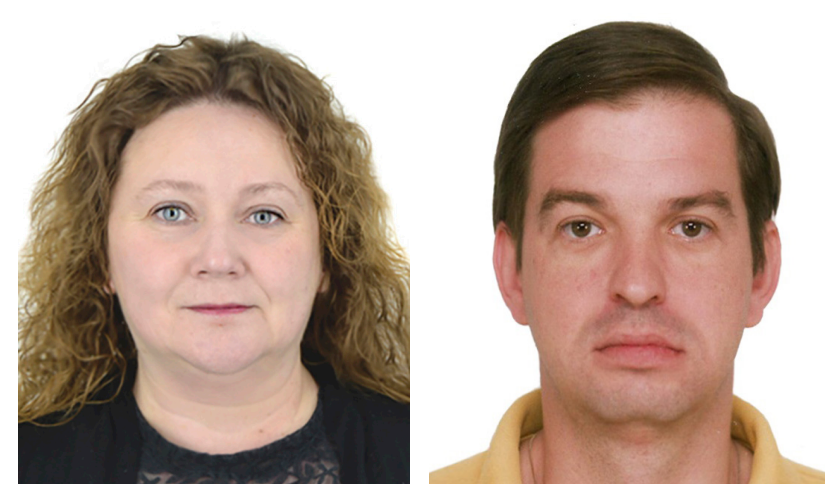

В статье анализируются визуальные образы, которые наполняют окружающий мир старообрядцев-часовенных Тувы. Кодирование информации через визуальные потоки обусловлено активной культовой деятельностью старообрядческой общины и находит выражение в различных формах народного искусства. При системном анализе визуальной культуры использованы материалы экспедиционных исследований авторов в старообрядческих поселениях в верховья Енисея (Эржей, Ужеп, Сизим и Сарыг-Сеп Каа-Хемского кожууна) Республики Тыва в 2016-2017 г2.

Наполняемость сакрального пространства культовыми предметами регламентирована религиозными доктринальными установками Соборных постановлений. Мир сакральных образов встраивается в повседневную культуру и наполняет профанное пространство. Здесь формируется свое восприятие визуального пространства с определенным набором ограничений, которые касаются одежды и использования различных предметов из внешнего мира. Отказавшись от телевизоров и компьютера, старообрядцы активно выписывают журналы, как для детей, так и взрослых, используют тиражированные открытки для поздравлений. Копирование образцов журнальной графики или книжных иллюстраций можно встретить в образцах народных промыслов. При запрете на фотофиксацию человека, в старообрядческих домах достаточно часто встречаются фотоальбомы, отражающие повседневную жизнь человека с 1960-х г2. до сегодняшнего дня.

Можно сделать вывод о взаимовлиянии у старообрядцев Тувы традиционной и массовой культуры при конфессиональном декларативном отрицании последней.

Ключевые слова: старообрядчество; Тува; визуальная культура; народная культура; народная картинка; культура повседневности; массовая культура; народные промыслы

* Выполнено при поддержке РФФИ (проект «"Енисейский меридиан” старообрядчества: сохранение и развитие традиции в условиях таёжных скитов и деревень», грант № 18-09-00723A).

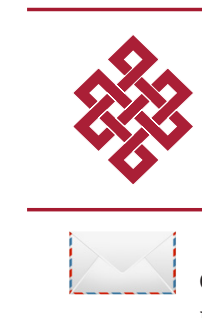

Для цитирования:

Быкова Е. В., Пригарин А. А. Мир визуальных образов старообрядцев Тувы: от иконы и лубочной картинки до фотографии [Электронный ресурс] // Новые исследования Тувы. 2019, № 1. URL: https:// nit.tuva.asia/nit/article/view/803 (дата обращения: дд.мм.гг.). DOI: 10.25178/nit.2019.1.6

Быкова Екатерина Васильевна - кандидат искусствоведения, доцент кафедры культурологии, социологии и философии Института гуманитарных и социальных наук Вятского государственного университета. Адрес: 610000, Россия, г. Киров, ул. Московская, д. 36. Тел.: +7 (8332) 74-24-71. Эл. адрес: ev2_74@mail.ru ORCID:0000-0002-6024-5398

Пригарин Александр Анатольевич - доктор исторических наук, профессор кафедры археологии и этнологии Одесского национального университета им. И. И. Мечникова. Адрес: Украина, 65000, г. Одесса, ул. Дворянская, д. 2. Тел.: +380 (48) 723-62-87. Эл. адрес: alexand@gmail.comＯRCID:0000-0002-6684-309X

Bykova Ekaterina Vasilyevna, Candidate of Arts, Associate Professor of the Department of Culture Studies, Sociology and Philosophy, Institute of Humanities and Social Sciences, Vyatka State University. Postal address: 36, Moskovskaya St., Kirov,610000, Russian Federation. Tel.: +7 (8332) 74-24-71.E-mail: ev2_74@mail.ru

Prigarin Aleksandr Anantolyevich, Doctor of History, Professor of the Department of Archeology and Ethnology, Odessa, I. I. Mechnikov National University. Postal address: 2, Dvorianskaia St., Odessa, 65000, Ukraine. Tel.: +380 (48) 723-62-87.E-mail: alexand@gmail.com 


\title{
The world of visual images of the Tuva Old Believers: from icons and popular prints to photos"
}

\author{
Ekaterina V. Bykova \\ Vyatka State University, Kirov, Russian Federation, \\ Aleksandr A. Prigarin \\ I. I. Mechnikov National University, Odessa, Ukraine
}

\begin{abstract}
The article analyzes visual images that fill the life environment of Chasovennye ('chapel-going') Old Believers of Tuva. The coding of information through visual streams is augmented by the religious activities of the Old Believer community and finds expression in various forms of folk art. Our systemic analysis of visual culture is based on expedition research materials which had been in use at Old Believers' settlements in the upper reaches of the Yenisei (Erzhey, Uzhep, Sizim and Saryg-Sep, Kaa-Khem kozhuun (raion) of the Republic of Tuva) in 2016-2017.

How sacred space is filled with religious objects is regulated by doctrinal guidelines established by Council (Sobor) ordinances. The world of sacred images is built into that of everyday culture; it opens into the profane space without losing its sacred meaning. Having refused the use of television and computers, Old Believers are active subscribers to print magazines, both for children and adults, and frequently use postcards for congratulations. Copied fragments of magazine graphics or book illustrations can often be found in works of folk art of Old Believers. Despite the prohibition to take photos of people, Old Believer houses often feature photo albums focusing on the daily life of a family from the 1960s up to this day.

We can conclude that among the Old Believers of Tuva, traditional and mass culture interact and support each other, although lip service is paid to the declarative denial of the latter on confessional grounds.
\end{abstract}

Keywords: Old Believers; Tuva; visual culture; folk culture; folk picture; culture of everyday life; mass culture; folk crafts

\footnotetext{
" Supported by RFBR, project no18-09-00723A "The Yenisei Meridian" of the old believers: the preservation and development of traditions in a taiga monasteries and villages.
}

\section{Введение}

В эпоху глобализации историко-культурный опыт старообрядчества, сумевшего в условиях гонений и неприятия государственной власти отстоять свою самобытность, представляет особую ценность для решения задач сохранении традиционной русской культуры. Визуальные образы в жизненном пространстве старообрядцев - это собственная модель репрезентации мира, где в тесной взаимосвязи отражаются религиозные представления и повседневность. Предметно-пространственная среда, в которой они живут, имеет свои визуальные маркеры, представленные как форма идентификации и самовыражения, образ жизни и мировоззрение.

Основная цель статьи - показать механизмы формирования и функционирования художественных и повседневных образов визуального мира старообрядцев-часовенных, проживающих в Республике Тыва (Туве). Источниковой базой исследования стали полевые материалы, собранные авторами в Туве в 2016-2017 гг. (хранятся в архиве авторов). Их системный анализ позволил выявить современные модификации традиционных визуальных и вербальных об- 
разов в повседневной культуре старообрядческих общин Тувы. Собранный полевой материал вводится впервые в научный оборот, что позволит расширить базу данных по изобразительным источникам народного искусства Сибири, характеризующих повседневный мир староверов часовенного согласия.

\section{Обзор исследований}

Старообрядцы Тувы являются переселенцами из различных регионов России, о чем свидетельствуют не только архивные документы, но и маргиналии ${ }^{1}$ в книгах и на оборотах икон, предпочтения в иконографии Распятия и сопроводительные надписи в навершиях культовых предметов. Символы, знаки и коды создают коммуникативную систему через визуальный и вербальный текст, благодаря которой в этой конфессиональной среде хранится и передается информация.

Методы описания и контент-анализ визуальной повседневной среды старообрядцев были предложены В. В. Керовым в контексте исследования конфессионально-этических факторов старообрядческого предпринимательства (Керов, 2016). Документальный материал о повседневной жизни старообрядцев в поселениях на Малом Енисее и в скитах, деятельности книжников и иконописцев, впервые в 60-70-е годы XX века был собран известными новосибирскими историками и филологами Н. Н. Покровским, Н. Д. Зольниковой, О. Д. Журавель. «С тувинских полевых исследований началось археографическое открытие Сибири, о котором позже напишут академики Д. С. Лихачев и А. М. Панченко» (Зольникова, 2018: 152). Опубликованные описания экспедиций в Туву новосибирской группы ученых представляются уникальным материалом для сравнительного анализа современного состояния старообрядчества на Енисее (Урало-Сибирский патерик, 2016).

Архивные и экспедиционные материалы по заселению и миграционным потокам старообрядцев на Енисее, собранные А. А. Стороженко, позволяют воссоздать историко-культурный контекст бытования в Туве этой конфессиональной группы в хронологической последовательности (Стороженко, 2015).

Известный исследователь староверов Тувы М. П. Татаринцева подробно рассматривает обряды и традиции, народный быт и фольклор в монографии «Старообрядцы в Туве: историкоэтнографический очерк» (Татаринцева, 2006). Ценным визуальным материалом в монографии является приложение с рисунками в старообрядческих деревнях Каа-Хемского района, сделанных во время Комплексной историко-этнографической экспедиции художницей Н. Корчугановой (июль 1986 г.). Портреты староверов в традиционных костюмах, бытовые зарисовки интерьеров и предметов быта помогают воссоздать предметно-пространственный мир через графические визуальные образы. Экспедиционные исследования и находки в поселениях Тувы обобщены в ряде статей научных журналов (Любимова 2004, 2009; Казанцева, 2017).

Как показывает современный анализ опубликованных архивов полевых материалов экспедиций, которые проводились Институтом истории СО РАН под руководством профессора Н. Покровского в конце 1960-1970 гг., ранее недостаточное внимание уделялось описанию визуального мира старообрядчества, предметно-пространственной среде, которую они создают и в ней живут, что объясняется археографической направленностью сбора материала (Зольникова, 2018).

Синтез культурно-антропологического подхода с искусствоведческим анализом на основе экспедиционных исследований материальной культуры старообрядцев позволяет рассмотреть визуальный мир и соотнести его с мировоззрением. Тем самым, при обследовании ста-

${ }^{1}$ Маргиналии - рисунки и записи на полях книг, рукописей, оборотах икон, содержащие комментарии, относительно фрагментов текста или мысли, вызванные ими. 
рообрядческих поселений Тувы мы уделяли пристальное внимание выявлению источников и анализу коммуникативной системы, формирующей визуальный и вербальный мир консервативного конфессионального сообщества.

Как отмечал один из основателей семиотики Ч. Моррис, человеческая цивилизация невозможна без знаков и знаковых систем (кодов), а человеческий разум неотделим от функционирования знаков (Моррис, 1983). Создание своей знаковой системы, интерпретация визуальных кодов и символов - наиболее распространенные приемы утверждения и отстаивания доктринальных позиций в старообрядческой среде. Они находят свое выражение в полемических сочинениях. Подобные полемики ведутся начиная с XVII века и продолжаются до сегодняшнего дня.

В настоящем исследовании мир визуальных образов старообрядцев Тувы представлен на трех уровнях осознания и связан с жизненным пространством. Первый уровень наиболее доктринальный и консервативный, четко регламентированный религиозным мировоззрением - это сакральное пространство моленной и частного дома, наполненное иконами и другими культовыми предметами, к которым обращаются во время моления. Второй уровень визуализации является промежуточным между сакральным миром и повседневностью, он является своеобразным проводником и коммуникационным каналом. Именно на Енисее были найдены народные картинки - лубки, которые выполняют эту функцию. На третьем уровне представлена повседневная культура старообрядцев, которая регламентирует визуальное наполнение предметно-пространственной среды, где живет человек: от его внешнего вида - до предметов, используемых в быту. Предметное пространство старообрядцев, создается как самими носителями культуры, так и привносится извне. Такие знаки современного мира, как аббревиатуры, штрих-коды и т. п., подвергаются критике со стороны консервативно настроенного старообрядческого сообщества и переводятся в сферу эсхатологических представлений. При этом отдельные элементы массовой культуры все-таки проникают в современный быт старообрядцев-часовенных Тувы.

\section{Сакральное в личном и общественном пространстве старообрядческой общины Тувы}

Визуальные образы той или иной старообрядческой группы и их формирование напрямую связаны с особенностями их картины мира, верованиями, представлениями об общественном и личном пространстве.

Одним из самых распространенных визуальных символов старообрядцев является трисоставной восьмиконечный крест, соответствующими сопроводительными надписями. Зрительный образ Креста должен напоминать им крестные страдания Христа, будь это крест в моленной или дома, или нательный крест, или крест на могиле. Крест сопровождает старообрядца всю жизнь. Символично, что жизнь христианина начинается с надевания на него креста во время крещения, сопровождается крестом во всех важных событиях и заканчивается крестом, который водружается над его могилой. Нательные кресты у старообрядцев имеют отличительную особенность: никогда не изображается распятый Христос. В отличие от других согласий старообрядчества, которые используют разные кресты для мужчин и женщин, часовенные принимают только мужской нательный крест для тех и для других. На основе собранных материалов нами было выявлено, что изготовлением нательных крестов в Верховье Енисея до 1980-х годов занимались мастер Евграф Сахаров из Ужепа, приехавший с севера Красноярского края, и в скитах отец Аввакум.

Сегодня в Чодураалыге Каа-Хемского района кресты льет Фёдор Балабанов. Заниматься литьем или, как говорили, творить «русскую медь» было технически не очень сложно, получались небольшие изделия без эмалей и огневого золочения. Изучение образцов старооб- 
рядческой меднолитой пластики позволяет выделить местную работу нательных крестов. Кресты делались для членов своей общины, а не на продажу. Кроме местного енисейского литья часовенные также используют крестики, произведенные в мастерских г. Новозыбкова Русской Древлеправославной церкви (беглопоповцы). В последние десять лет их привозят из монастырей Дубчеса ${ }^{1}$. Кресты со Среднего Енисея встречаются повсеместно.

Меднолитые киотные восьмиконечные кресты с изображением в своем навершии Саваофа и голубем маркируют ключевые сакральные точки жизненного пространства старообрядцев. Они присутствуют в составе иконостасов в моленных и в домашних красных углах, а также в передних углах лесных охотничьих избушек. В современном частном доме насчитывается до пяти распятий в различных помещениях. Встречаются металлические распятия, врезанные в доску, а также с живописным дополнением предстоящих святых. Подобные составные иконы с живописными дополнениями предстоящих святых особенно популярны были в уральском иконописании начала XX века. Сегодня на Дубчесе продолжают эти традиции, используя невьянские образцы. Именно эти два источника и пополняют частные собрания икон и моленных старообрядцев-часовенных Малого Енисея.

Крест, представленный в различных техниках исполнения, в виде литых и резных, иконописи, шитых голгофах - наиболее распространенный символ, имеющий свою специфику в изображении. Различные типы распятий свидетельствуют о слиянии традиций поповского и беспоповского согласия у часовенных в почитании креста с различными сопроводительными надписями. В моленных старообрядцев-часовенных, реже в частных домах Каа-Хемского района, были зафиксированы «малые и большие патриаршие Распятия», характерные для поповского согласия. «Малое патриаршее Распятие» представляет собой композицию, состоящую из киотного креста с изображением Распятия с предстоящими и пяти клейм с праздниками, завершающуюся венцом из шести серафимов и херувимов. Это завершение символизирует торжественные пасхальные песнопения. Подобные кресты гуслицкой и уральской работы конца XIX - начала XX в. регулярно встречаются в частных домах старообрядцев на Малом Енисее. «Большое патриаршее Распятие» является по своему иконографическому замыслу иконой-календарем. Большие кресты с изображениями праздников, украшенные своеобразной короной из прорезных серафимов и херувимов, представляют собой иконостас с Распятием в центре. Праздничные композиции расположены не по хронологии евангельских событий, а по богослужебному годовому кругу. Подобные кресты без эмалей конца XIX - начала XX в. московской и гуслицкой работы встречаются редко.

В старообрядческом искусстве двуперстие часто является смысловым центром всего произведения, как вызов и утвердившееся противостояние реформам Никона и последующих церковных и государственных деятелей. «Десница Всевышнего» - это маркер культурной и конфессиональной идентификации старообрядчества. Ей отводится центральное смысловое значение, как символу покровительства праведников над всеми идущими по «узкому пути» ${ }^{2}$. Символическое изображение благословляющего Двуперстия Господа в иконе - это указующий перст праведного пути, символ могущества и силы, защита от пришествия Антихриста.

По нашим экспедиционным материалам 2017 г., а также собранной новосибирскими учеными переписке между старообрядцами штата Орегона (США) и общинами на Енисее об иконографических особенностях изображения двуперстия на иконах Богоматери в среде часовенных произошел раскол в начале 2000-х годов о принятии образов и современном их написании (Зольникова, 2008, 2009). Суждения о расколе по поводу особенностей изображения десницы на иконах Богоматери актуальны и в общинах Тувы, что подтверждают полевые за-

\footnotetext{
${ }^{1}$ Духовный центр старообрядцев-беспоповцев часовенного согласия, на притоке Енисея - р. Дубчес (Красноярский край).

${ }^{2}$ «Входите тесными вратами, потому что широки врата и пространен путь, ведущие в погибель, и многие идут ими потому что тесны врата и узок путь, ведущие в жизнь, и немногие находят их» (Матф.7:13-14).
} 
писи. Подобный факт говорит о рефлексии в отношении значимых символических изображений, согласно представлениям старообрядцев, освященных древней традицией.

Сакральное пространство тесно связано с вопросом об устройстве старообрядческой моленной. Изучение конструктивных особенностей и программы иконного убранства моленной осложнено запретом фотофиксации в полевых условиях. Поэтому описание моленной основано на первичном визуальном анализе без детализации. Подобное описание мы находим и в опубликованных дневниках экспедиции Н. Н. Покровского 1967 г. (Урало-Сибирский патерик, 2016: 173). Как показали полевые исследования, в старообрядческих поселениях Тувы (Эржей, Ужеп) моленная - это отдельно стоящая изба, которая ничем не отличается от других домов. Визуальные маркеры, выделяющие эту культовую постройку, в сельском ландшафте отсутствуют. В моленных нет алтаря, так как она не предназначена для совершения евхаристии. Скромные пристенные конструкции в виде полок, приделанных к восточной стене, являются имитацией иконостаса. Иконное наполнение моленных включает разновременные поступления, иконы характеризуются различными размерами, техникой исполнения и датировкой. Внутренне пространство лишено единого художественного решения. В основном это сочетание живописных икон и металлопластики.

Иконография традиционная: несколько типов крестов, Богоматерь Одигитрия, Богоматерь «Всех Скорбящих Радость», Господь Вседержитель, Св. Николай Чудотворец, Св. Илья Пророк, Святой апостол Иоанн Богослов. В моленной иконы двунадесятых праздников представлены разрознено или встречаются в виде металлических складней. Интересно отметить, что в этом регионе в моленных и частных собраниях иконы в металлических окладах не встречаются. Преобладают в основном иконы уральского письма (Невьянск), а также позднее народное письмо, с характерными локальными особенностями сибирской поздней иконы: крупным цветочным орнаментом, использованием красной киновари и окиси хрома. Иконы, написанные на досках, имеют ковчег или в поздней работе его имитацию. В старообрядческих поселениях моленная не только выполняет функцию богослужебного и вероисповедного помещения, но и своеобразного коммуникативного центра с просветительными и воспитательными и учительными задачами. Этим объясняется то, что при входе в моленной Эржея и Ужепа КааХемского района висел современный лубок (позже убран), привезенный с Дубчеса. В 2017 г. в Эржее также фиксировали появление карандашного портрета с изображением о. Гурия - монаха, трагически погибшего от медведя, спасая насельниц женского монастыря, ушедших в лес по ягоды. Появление этого портрета в моленной не случайно и объясняется проживанием родственников в этом поселении. В моленной отсутствует электричество, все службы идут при свечах, что создает особый эмоциональный настрой.

Ситуация пополнения иконами моленных и частных домов осложняется решениями Соборного уложения в Китае от 31 марта 1953 г. В них в пункте 1 записали «О поклонении четных икон: следует поклонятся иконам древним и християнскими иконописцы писаным (Стоглав, глава 43). А иноверными иконописцы писаным или литым (иконам) не поклоняться и не приобретать их» (Духовная литература ..., 1999: 381). Для выполнения подобных требований, сформулированных на Соборах необходимо было развивать скриптории и иконописные мастерские. До недавнего времени скиты на Малом Енисее (в частности отцов Палладия, Аввакума) были такими книжными, литературными и художественными центрами. По записям экспедиции Н. Н. Покровского в 1967 г. в скиту у отца Палладия иконы подправляли сами. «Палладий рассказывал, что потомственный изограф Михаил Кузмич Ковин живет в Сизиме. Его предки известны в XIX в. (часовенное согласие). Он был капитаном Енисейского пароходства» (Урало-Сибирский патерик, 2016: 173).

Сегодня главным поставщиком религиозно-художественной продукции для своих единоверцев стал Дубчес. Сейчас, приезжая из паломнических поездок (нередко включающих в себя посещение своих монастырских родственников) в Дубчесские обители, старообрядцы при- 
возят оттуда новые образа традиционной иконографии с изображением Спаса Вседержителя, Богоматери и др. В экспедиционных поездках нам встречались иконы с изображением Богоматери в бисерных окладах, привезенных из монастырей.

При обследовании частных домов фиксируется, что на полях икон написаныпатрональные святые: св. Евдокия, св. Андрей, св. Евстафий, св. Иоанна воин и Ангел-хранитель. В красном углу старообрядца находятся как живописные иконы, так и металлопластика в виде складней и отдельных небольших образов с избранными святыми, как правило, патрональными (фото 1). При

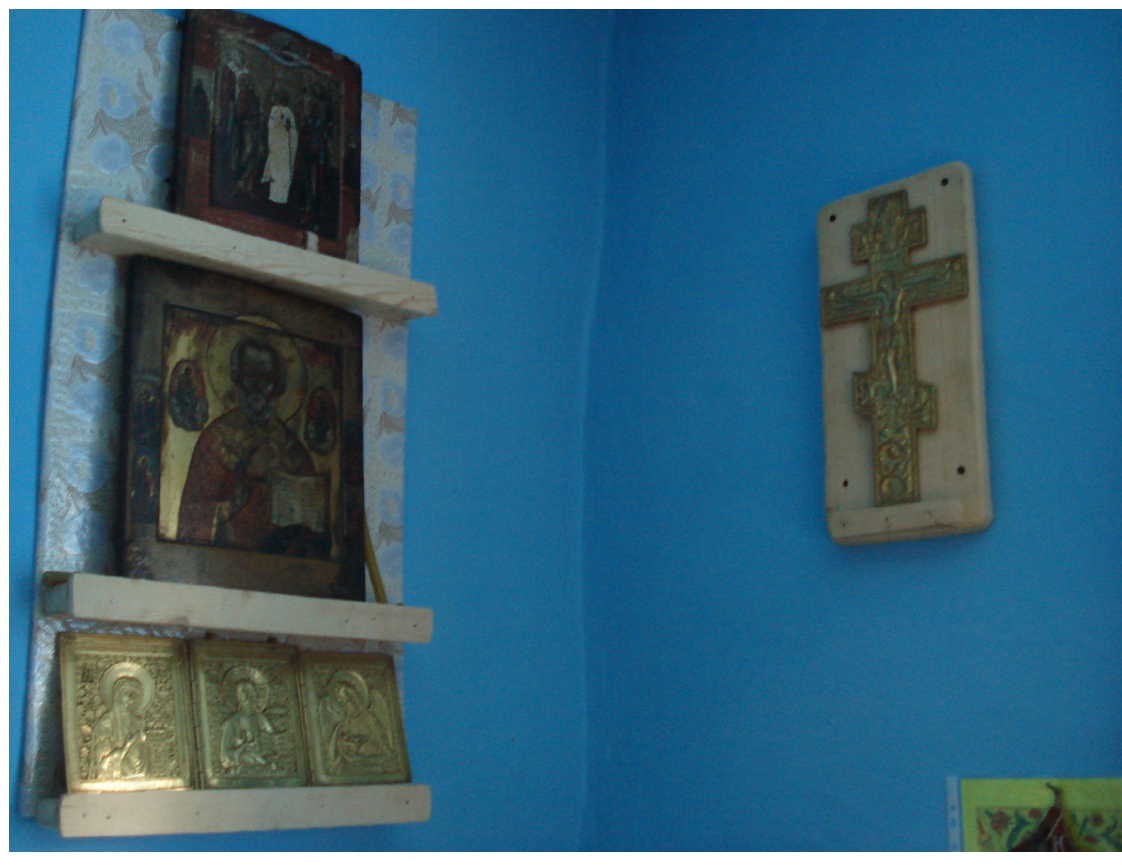

Фото 1. Красный угол в частном доме старообрядцев-часовенных. Каа-Хемский район. Фото А. Пригарина, 2016 г.

Photo 1. "Red corner" in a private house of Chasovennye Old Believers. Kaa-Khem raion. Photo by A. Prigarin, 2016. количественном анализе иконографического состава образов в частных домах старообрядцев-часовенных этого региона бытование сюжетных икон со сложными композициями не распространено.

Один из интересных образцов редкой иконографии Богоматери с акафистом «О, всепетая Мати» был описан нами во время экспедиции 2017 г. из личного собрания икон в Эржее. Икона XIX в. была принесена из Кузнецкого края (Кемеровской области) и представляет традиционное письмо тонкой работы и орнаментальной проработкой. В металлопластике трехстворчатые складни «Деисуса» широко распространены среди населения и находятся в каждой старообрядческой моленной и частных домах. Створки металлических складней двунадесятых праздников, как правило, разрознены и это объясняется информантами, как деление икон между членами семьи.

Интерес представляют деревянные резные кресты, которые, по словам старообрядцев, делал о. Аввакум в скиту. Неглубокая рельефная резьба, мелочная проработка деталей на Распятии свидетельствуют о мастерской индивидуальной манере. По словам современных старообрядцев, в скитах писали иконы, делали литые и резные кресты, а также переписывали и печатали книги. К этим предметам они относятся с большим почтением, наделяя их сакральным смыслом. Как показали наши междисциплинарные экспедиции 2016-2018 гг. в Верховье Енисея, как при обследовании моленных и частных домов, а также при личных беседах, что сегодня традиции книгописания, литья и иконописания утрачены.

Кладбище в старообрядческих поселениях представляет собой сакральное пространство, со своей семантической организацией пространства (фото 2). В обследованных населенных пунктах Эржея, Сизима и Ужепа Каа-Хемского района Республики Тыва кладбище находится на возвышенности недалеко от поселений. Могилы на староверческих кладбищах ориентированы вдоль линии «восток - запад». Намогильный крест часовенных - это также восьмиконечный крест из дерева. Более старые кресты относятся к типу северных крестов-голбцев с крышей. Меднолитое Распятие является обязательным атрибутом похоронно-поминального обряда и крепится к намогильному кресту. 


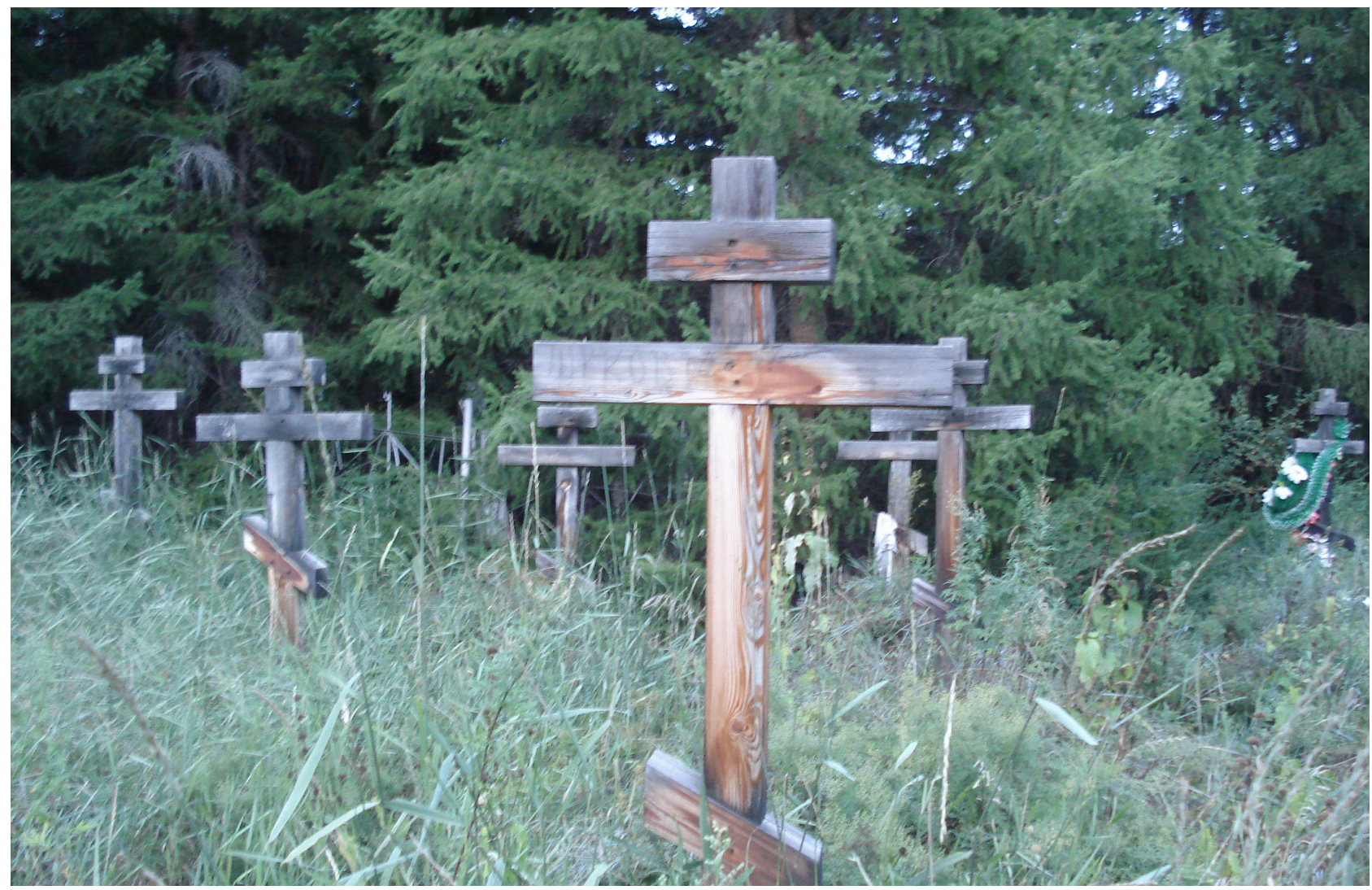

Фото 2. Староверческое кладбище. Сизим. Каа-Хемский район. Фото А. Кострова, 20162. Photo 2. Old Believers Cemetery, Sizim, Kaa-Khem raion. Photo by A. Kostrov, 2016.

В традиционных представлениях старообрядческая культура - это культура слова и книги. Старообрядческая книга отличается особым художественным оформлением: книжные переплеты из кожи с тиснением и застежками, орнаментальные заставки, книжные миниатюры, буквицы и шрифты. Все эти элементы художественной структуры книги подчеркивают особую эстетику, формирующую визуальное жизненное пространство старообрядцев, наполняя его сакральными символами. Книжно-рукописное мастерство, получившее распространение в старообрядческих скитах Тувы и Красноярского края, является одним из визуальных каналов распространения сакральной знаковой системы в локальных общинах. Известный исследователь старообрядческой книжности Н. Ю. Бубнов, определяя старообрядческую книгу как историко-культурный феномен, отмечает, что «старообрядческая книга, искусственно оторванная от типографий, являлась по существу постпечатной книгой, обладавшей целым набором признаков, свойственных печатной книге. Создатели рукописных книг не только стремились придать внешнее сходство с печатной книгой, копируя “полууставный” шрифт, заставки и инициалы печатного книжного орнамента, переплеты Печатного двора, но и начиная с 1667 г. стали называть составленные ими рукописные сборники книгами, стремясь в глазах читателей уравнять их в правах с официальными печатными изданиями» (Бубнов, 1995: 39).

В частных коллекциях старообрядцев Енисея представлены богатые книжные собрания, нередко состоящие из десятков рукописных и старопечатных сборников (конволют), книг гражданской печати. География изданий старопечатных книг обширна: Москва, Вильно, Клинцы, Гродно, Супрасль и т. д., что свидетельствует о коммуникационных связях староверов по всей России. В старообрядческих скитах Тувы традиционно «реставрировали» и переплетали книги. О. Аввакум резал шрифты и орнаментальные штампы для заставок и концовок, печатал книги. В экспедиции была найдена Псалтырь, напечатанная о. Аввакумом $\left(4^{\circ}\right.$, переплет тканевый, черный). Сегодня выписываются: поморские календари из Москвы и ли- 
тература из г. Новозыбково Брянской области и г. Верещагино Пермского края. Рукописная книжная культура формировалась в старообрядческих скитах, впитала в себя традиции исполнения древнерусской книги, принципы оформления рукописей, в том числе и простыми орнаментальными заставками (Стороженко, 2016). Большинство рукописных сборников выполнены небрежным полууставом и почерком, подражающим письму кириллических книг. В то же время рукописи конца XX века нередко созданы на листах из школьной тетради. В старообрядческих общинах на Малом Енисее особой популярностью пользуются рукописные Месяцесловы, Молитвенники, Тропари и кондаки, Цветники различного содержания с цитатами из Великого Зерцала, Четьи-Минеи, Пролога, Кормчей и т. д.

Таким образом, сакральное пространство старообрядческой общины на Енисее складывается из традиционных элементов, наполняющих общественную и личную среду старообрядцев-часовенных. Конфессиональная символика и сакральные предметы (иконы, кресты, книги) наполняют жизненное пространство старообрядцев, в котором бережно хранят наследие предков и воссоздают утраченное внутри конфессиональной группы, учитывая локальные традиции и доктринальные установки Соборных постановлений часовенных.

\section{Визуальный мир современной народной старообрядческой картинки}

Во время экспедиций в 2015-2018 гг. на Енисей нами были обнаружены уникальные растиражированные народные картинки, в которых художники показали особенности жизни общины (название картинки «Две дороги - два пути»), а также личностно-индивидуальный путь старообрядца («Возраст и действа и обычаи жизни человеческой. Зри лет жития...»), предостерегающий его от соблазнов мирской жизни и впадения во грехи. Было выявлено 12 образцов народной картинки, которые размножены с рисованных образцов. В общинах Тувы встречается только растиражированный вариант. Согласно данным, полученным нами от информантов, современный рисованный лубок создан в старообрядческих монастырях часовенного согласия на Среднем Енисее.

Образы старообрядческих народных картинок являются развернутым визуально-текстовым повествованием о праведной и греховной жизни. Народная картинка выполняет воспитательные функции, а также является коммуникационным каналом.

Соборные постановления, регламентирующие правила жизнеустройства проиллюстрированы в картине «Две дороги - два пути». Подробный анализ сюжетной линии предложен нами в другой публикации (Быкова, Костров, 2018a), в настоящем исследовании акцент необходимо сделать на выразительных средствах этого лубка и соединении традиционного древнерусского искусства с постмодернистскими тенденциями (фото 3).

Цитируемость как священных и авторских старообрядческих текстов, так и визуальных образов, позволяет создавать сложное многоуровневое по восприятию произведение народного изобразительного искусства. Художник картинки намеренно подчеркивает окантовкой, как опушь на иконе, сакральность мира: широкий путь - красный цвет, узкий - синий. Соединение визуальных образов древнерусской книги и иконы (десница, пасть зверя) с журнальной графикой и открыткой (статуя Свободы, Московский Кремль) создает особый мир народного изобразительного фольклора, в сопровождении современных духовных стихов: «Подумай бедный человек» и «Побуждение к борьбе со грехами». Назидательность картинки и стихов должна приводить человека к размышлением о своей судьбе и окружающем мире, в котором он живет: «Подумай благолепный человек // Для чего ты стал человеком? // Для искушения отданный // Миродержателю сей век. // Для того чтобы ты стал богочеловеком // А не черточеловеком - медеумом...»

Эсхатологическая тема находит интересное воплощение в визуальных образах старообрядческих лубков, обнаруженных на Енисее во время экспедиций 2016-2017 гг. Рисованная картина «Всемирная сеть. Мировая паутина» была выполнена 3 апреля 2010 г, о чем свидетельствует надпись в нижнем углу, после стиха. Здесь же сделана приписка: «Просим про- 


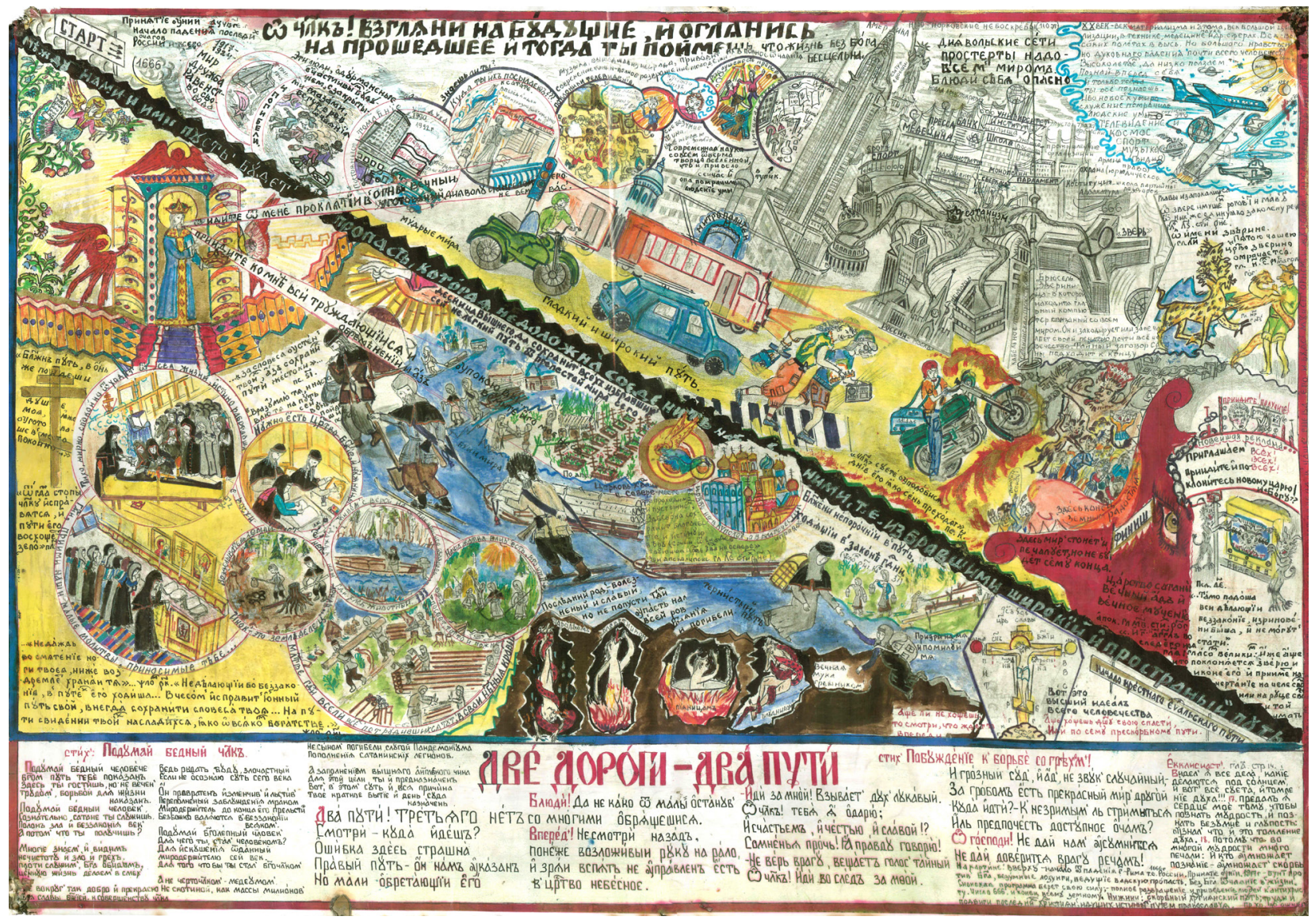

Фото 3. Старообрядческий рисунок «Две дороги - два пути», создан на Среднем Енисее (Дубчес). Выявлен в Каа-Хемском районе Республика Тыва в 2016 г.

Виервые опубликован в журнале «Традиционная культура» т. 19. № 22018 г.

Photo 3. Two roads - Two ways, a drawing by an Old Believer, made at the Middle Yenisei (Dubches). Obtained in Kaa-Khem raion of the Republic of Tuva in 2016. First published in the Traditsionnaya Kultura journal, vol. 19. No. 2, 2018.

щения за ошибки. И помолитесь ГБ (Господу Богу. - Е. Б., А. П.) за детей», что явно следует рукописным книжным традициям переписчика в концовке.

Лубочная картинка «Всемирная сеть. Мировая паутина» посвящена актуальной теме современности: проблемам глобализации и научно-техническому прогрессу с внедрением компьютерных технологий (фото 4). Интернет-паутина трактуется как движение к концу света и имеет назидательное содержание. Художник показывает всемирную сеть как паутину. В центре большой паук, сидящий на земном шаре, пожирает человека как «жертву дьявола», от него отходит паутина. На пауке изображен сатана в виде черта с рогами и копытами, числовым обозначением 666 и над ним надпись «единое мировое правительство/ единая мировая религия». Под пауком надпись: «Последние минуты/ мировая история подходит к своему скончанию». Таким образом, художник говорит о пришествии Антихриста и «последних временах». Личность художника, создававшего эту народную картинку, представляется грамотным человеком, хорошо знакомым с новыми компьютерными технологиями. Об это свидетельствуют отдельные детали и подписи: «международный биомитрический стандарт», под телефоном изображены антенны HAARP ${ }^{1}$, ИНН, смарт-карта, микрочип, ноутбук с информацией о человеке и веб-камерой и т. д.

${ }^{1}$ От англ. High Frequency Active Auroral Research Program - программа исследования ионосферного рассеяния высокочастотных радиоволн. Ее считают психотропным и климатическим оружием массового поражения. В России есть в Васильсерске, Томске. 


\section{НОВЫЕ ИССЛЕДОВАНИЯ ТУВЫ}

www.nit.tuva.asia

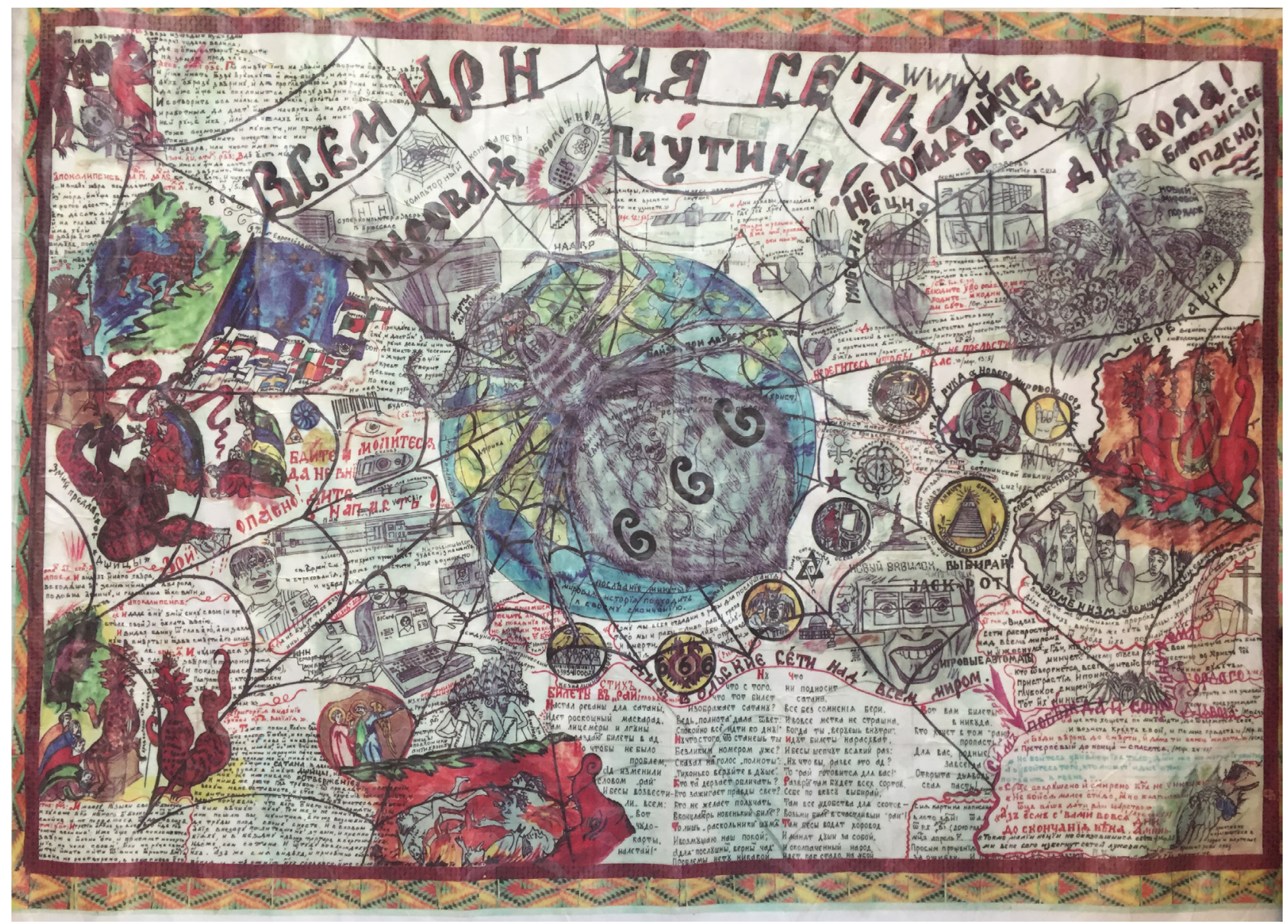

Фото 4. Старообрядческий рисунок «Всемирная сеть. Мировая паутина». Создан на Среднем Енисее (Дубчес). Выявлен в Каа-Хемском районе Республика Тыва. Фото из архива экспедиции 20172.

Photo 4. The World Wide Web, the Global Cobweb, a drawing made by an Old Believer at the Middle Yenisei (Dubches). Obtained in Kaa-Khem raion of the Republic of Tuva. Photo from the archive of the 2017 expedition.

Сложная визуальная композиция, с большим количеством символов сопровождается текстами из Апокалипсиса и современным старообрядческим духовным стихом «Билеты в “рай” (глобальный)». Приемы конструирования изобразительного поля и игра со словом сближают эти картинки, подчеркивая игровую концепцию лубка (Быкова, Костров, 2018b).

Другая рисованная картинка «Корабль веры», найденная в экспедиции 2017 г., - свободная изобразительная реплика лубка, где изображен крестный корабль как символ спасения (фото 5). Цитирование изображений с лубочных картинок и переработка под свои религиозные взгляды - один из любимых приемов в старообрядческом изобразительном искусстве. Спасение праведников на парусном корабле и черти на берегу, тянущие грешников в лодке, с транзистором на борту - яркий образец визуальной назидательности. По словам старообрядцев Эржея Каа-Хемского района, картина с кораблем им очень нравится своими яркими красками и понятностью.

Рисованные картинки о значимых двунадесятых праздниках, являющиеся своеобразным информационным и поздравительным листом, были выявлены в Республике Тыва в КааХемском районе в 2017 г. Информанты сообщили, что в Сарыг-Сепе подобные картинки привезены из Красноярского края, где они отрисованны и распространяются через копирование в виде цветной печати. Лист «Чесо ради червлено яйце на велик день, Пасхи», «Последний наш путь». Формат листа A3, тексты написаны чернилами и цветными ручками. Рисунки вы- 


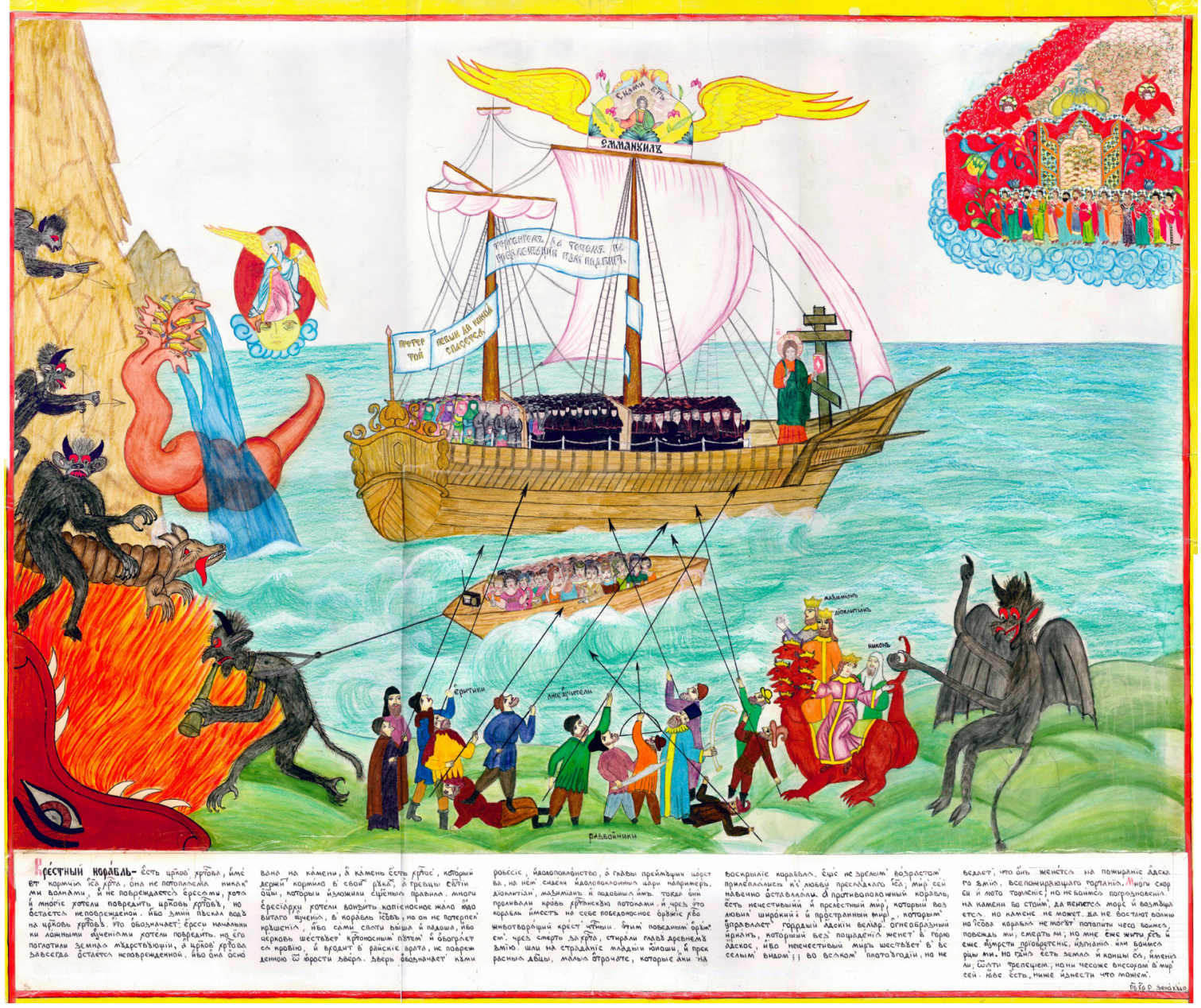

Фото 5. Старообрядческий рисунок «Корабль веры». Создан на Среднем Енисее (Дубчес).

Выявлен в Каа-Хемском районе Республика Тыва. Фото из архива экспедиции 2017 г.

Photo 5. The Ship of Faith, a drawing made by an Old Believer at the Middle Yenisei (Dubches). Obtained in Kaa-Khem raion of the Republic of Tuva. Photo from the archive of the 2017 expedition.

полнены простым карандашом, красками и мелками, представляют вариант визуального и вербального нарратива.

В листе «Чесо ради червлено яйце на велик день, Пасхи» (фото 6) объясняется значение яйца и его место в мироздании через писание Иоанна Дамаскина: «Яйцо применено ко всей твари. Скорлупка - аки облацы, Белок - аки воды, Желток - аки земля. А сырость среди желтых, аки в мире грехи...» Объясняется традиция обмена яйцами на Пасхе, ведущая свое начало от «Св. Марии Магдалины, которая подарила императору красное яйцо, как символ новой жизни с воскресшим Христом в Царстве Небесном». Ссылку автор рукописного листа делает на толкование в книге «Гранограф древлеписьменый». «При этом обмен яйцами (куриными), - окрашенными обычно в красный цвет, ибо в стихире поем “Пасха красна"». Цитатность и обращение к писаниям святых отцов - особенность старообрядческих рукописей. В рассматриваемом листе отсылка сделана к писанию святых отцов церкви Христовой - у Кирилла Иерусалимского, Блаженного Августина и других. Оформление открыточного типа в орнаментальной рамке и условное изображение крашенного красного яйца и вербы с общепринятыми аббревиатурами «Х.В. и ВВ.». Поздравление с Пасхой - один из интересных нарративов, соединяющих вербальные и визуальные коды и демонстрирующих заимствование открыточного источника, что указывает на влияние массовой культуры. С этим же листом сделана схема Пасхалии с 2010 до 2033 года (фото 7). 


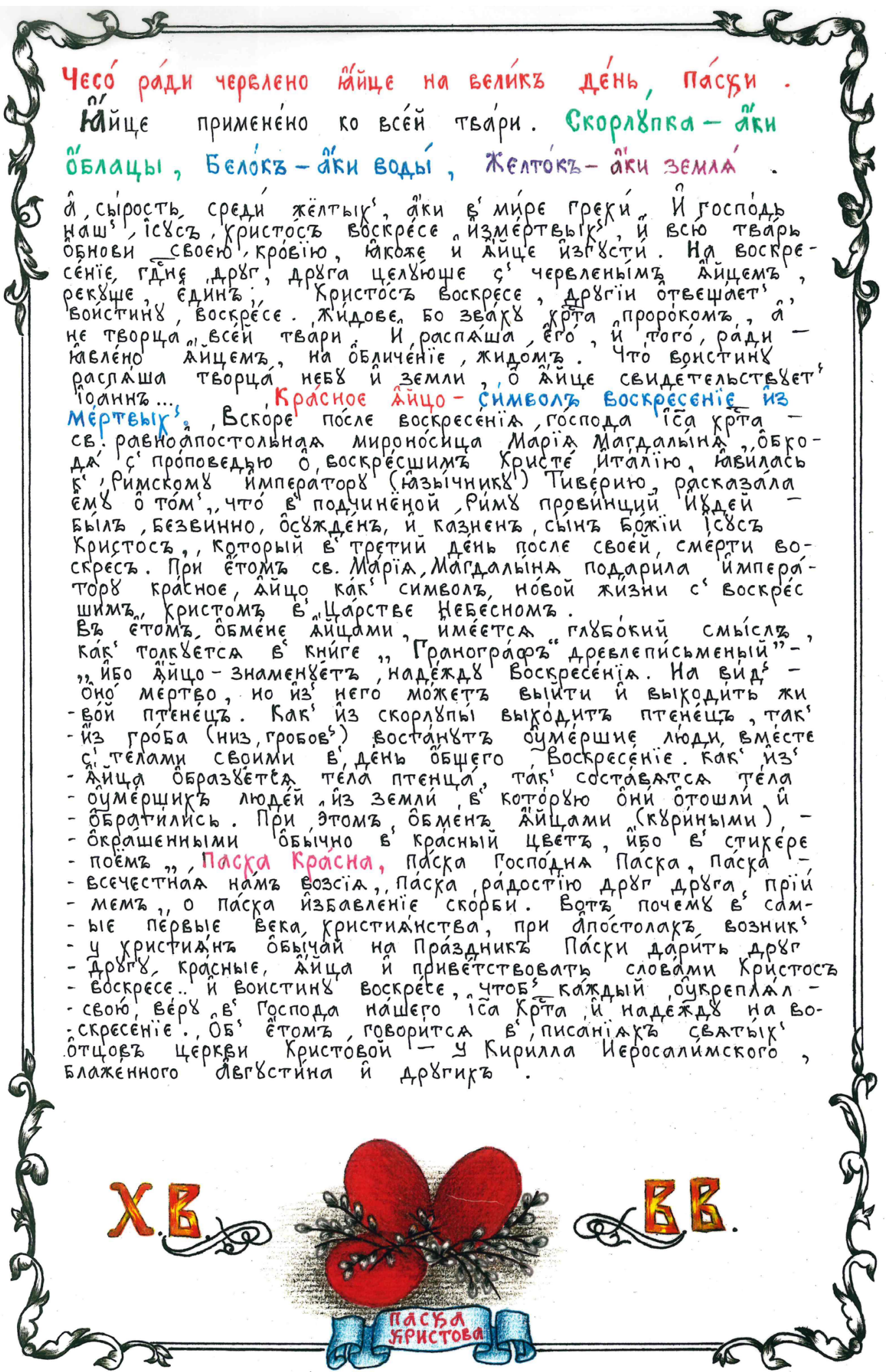

Фото 6. Старообрядческий рисованный лист «Чесо ради червлено яйце на велик день, Пасхи». Фото из архива экспедииии 20172.

Photo 6. Old Believer hand-drawn sheet "Why the scarlet egg [is used] for the great [Easter] day." Photo from the archive of the 2017 expedition. 

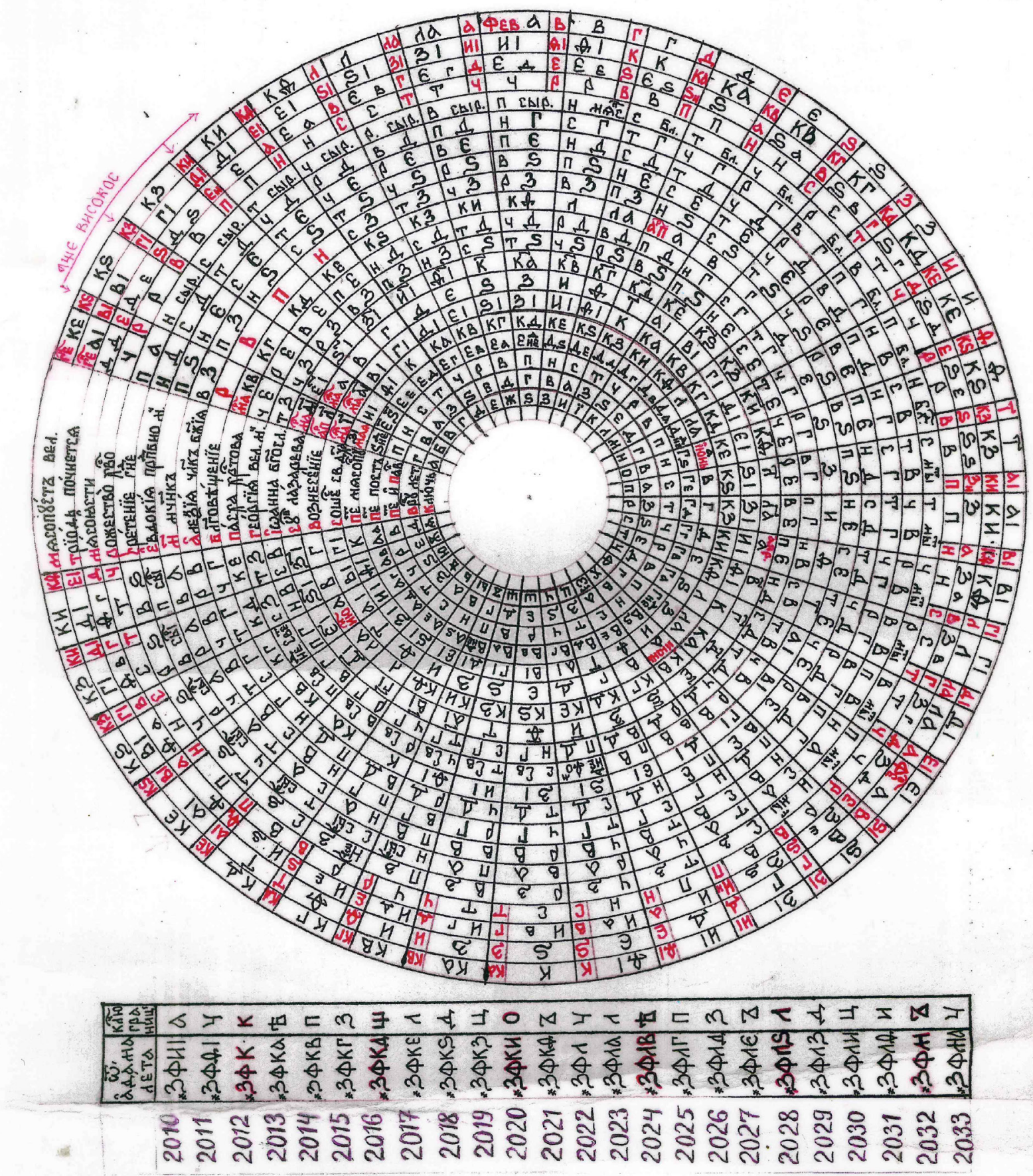

Фото 7. Пасхалия с 2010 до 2033 г. Фото из архива экспедиции 2017 г.

Photo 7. Easter calendar, 2010 to 2033. Photo from the archive of the 2017 expedition.

Таким образом, подобные картинки являются своеобразными назидательными коммуникативными каналами, через которые визуальными и вербальными средствами транслируются доктринальные мировоззренческие установки старообрядцев-часовенных. Подобные нарративы - уникальный источник изобразительного фольклора - являются медиатором между сакральным пространством и повседневной культурой с бытовыми элементами. Это подтверждается и местом бытования картинок от пространства моленной до частного дома. 


\section{Визуальный мир в повседневной культуре старообрядцев-часовенных}

Быт и уклад жизни староверов-часовенных Тувы отличает религиозность в различных проявлениях, в том числе и повседневных практиках. Визуальный образ старообрядца доктринально предписан и регламентирован. Одежда позволяет отличить своего от чужого в старообрядческой среде.

Вопросы о благочестии в одежде не раз обсуждались на старообрядческих Соборах, но строгой регламентации принято не было. «9. О одеждах необычных: смотреть настоятелям на местах, более придерживаться обычных одежд // по подобию исинных християн» (Духовная литература ... ,1999: 382). В 1994 г. на Сандакчесском соборе осудили надписи на одежде: «Также и дети многие носят одежду со всякими нашивками и рисунками разных животных и нерусскими буквами... И многие носят такую одежду, сами не знают, что на ней написано. Известен случай, когда нерусская надпись на одежде в переводе на русский язык означала «нечистый дух» (Покровский, Зольникова, 2002: 91).

Несмотря на жесткость регламентаций жизненного поведения и строгость старообрядческих наставников, призывавших единоверцев носить простую неброскую одежду, в современных условиях в старообрядческих поселениях часто можно видеть яркие одежды. За подобные нарушения накладывается епитимия. В местной среде осуждается обнажение человека, в том числе и частичное в общественных местах, не подкрепленное какими-либо обрядовыми предписаниями. Для женщины считается неприличным прилюдно появляться без головного платка. До сих пор в старообрядческих поселениях в Ужепе и Эржее женщины предпочтительно надевают только платья и сарафаны, исключая брюки и юбки. Короткая женская одежда также под запретом. Явные послабления в традиционном восприятии одежды можно увидеть в смене сдержанных цветовых решений (приглушенные охристые, коричневые, реже темносиние и черные оттенки) - на яркие (голубые, розовые, синие). В будние весенне-летние дни женщины соборно молятся в одежде из ситца или сатина, иногда шелка, в холода - из шерстяных и полушерстяных тканей. Платок крепят на булавку прямоугольником. Обязательной принадлежностью мужского и женского старообрядческого традиционного костюма является пояс. До сих пор в верховьях Енисея сохраняется один из древнейших способов создания поясов - тканье на дощечках. Различное цветовое решение, техника исполнения, материалы делают пояса нарядными и непохожими друг на друга. Редко встречаются пояса с молитвами.

Старообрядцы ответственно относятся к богослужению, к церковной службе и к тому, каким должен быть облик человека, предстоящего на молитве Богу. Обязательные атрибуты молитвенной жизни - лестовка ${ }^{1}$ и подрушник (подручник) ${ }^{2}$. По опросам старообрядцев КааХемского района, лестовка всегда должна быть при человеке, чтобы не отвлекаться на пустые мысли и постоянно пребывать в молитве. В экспедициях было выявлено три типа лестовок: повседневная лестовка для моления, богородичная и дорожная (маленькая). Ранее лестовки шили женщины или девицы, получившие благословление наставника. Сегодня большинство лестовок сделаны из шелковой ленты и привезены из монастырей Дубчеса, с которыми поддерживается тесная связь.

Дома старообрядцев достаточно аскетичны: в них отсутствует резьба наличников, украшения фронтонов и причелин. М. П. Татаринцева, известный исследователь старообрядцев Тувы, считает, что «в сознании переселенцев долгое время присутствовало ощущение, что живут они на чужой земле и власти их могут выслать в любой момент. Это также порой надолго задерживало строительство постоянного, добротного жилья, дома “на века”» (Татаринцева, 2006: 20). Это объясняет отсутствие художественной народной росписи и деревянной резьбы в убранстве домовых построек.

\footnotetext{
1 Лестовка - древнерусские православные четки.

2 Подручник (подрушник) - стеганый лоскут или подушечка, для того, чтобы при совершении земных поклонов руки во время молитвы оставались чистыми.
} 
Несмотря на то, что духовная, нравственная сторона жизни древлеправославного христианина остается относительно неизменной, материальная, бытовая сторона его жизни подверглась серьезной трансформации в результате повсеместного внедрения и распространения массовой продукции, оказывающейся зачастую более практичной и удобной в использовании. Ограничения на использование пищевых и различных предметов быта прописаны в старообрядческих Соборах часовенных. Сегодня появляются новые запреты, которые включают в себя визуальную знаковую систему: использование предметов со штрих-кодом, государственной символикой и т. д. В экспедиционных исследованиях мы встречали у населения тетради, книги с вырезанными штрих-кодами на обложках.

Синтез визуальных проявлений и представлений образует «общественную иконосферу» старообрядцев-часовенных, которая предстает как особый мир, наполненный своими зрительными образами. В ходе экспедиций в верховья Енисея нами были отмечены интересные факты формирования собственного визуального мира старообрядцев через проникновение отдельных элементов массовой культуры.

При отказе от телевизоров и компьютера, старообрядцы активно выписывают журналы, как для детей, так и взрослых, активно используют тиражированные открытки для поздравлений. О связи с миром через печатные СМИ еще указывал Н. Н. Покровский в своих экспедиционных дневниках 1967 г. Из его беседы с Зинаидой Филипповной Миковой (Долгих), которая жила в Ужепе, стало известно, что семья в конце 1960-х гг. выписывала газеты и журналы: «Тувинская правда», «Пчеловодство», «Охотничье хозяйство», «Крестьянка», «Работница», «Советский воин» (Урало-Сибирский патерик, 2016: 155). При нашем опросе во время экспедиции летом 2017 г. большинство информантов старообрядческого поселения Эржей назвали газету «ЗОЖ» как самую популярную и любимую для чтения, а также журнал «Жизнь, слезы и любовь» и детский журнал «3/9 царство». Таким образом, средства массовой информации и популярные журналы, в которых поднимаются наиболее жизненные проблемы, актуальны в старообрядческой среде и формируют своеобразный круг интересов, устанавливая коммуникационные каналы с современным миром. Журнальные вырезки и плакаты, а также репродукции картин встречаются на стенах жилых домов.

Использование образцов журнальной графики, иллюстрирования массовой литературы можно встретить в образцах народных промыслов. Образцы такой трансформации можно видеть в сундучном промысле, который сохранился и поддерживается в старообрядческой среде Тувы. Как показали наши экспедиционные исследования в Красноярском крае и в других регионах Сибири, данный промысел ушел в прошлое и не поддерживается. Изготовление сундуков и их дарение тесно связано со свадебным обрядом, в дальнейшем сундуки хранят как семейную реликвию, которая находится в жилом пространстве дома. В поселениях Каа-Хемского района (Эржей, Сизим) работают столяры, которые изготавливают на заказ подобные сундуки и украшают

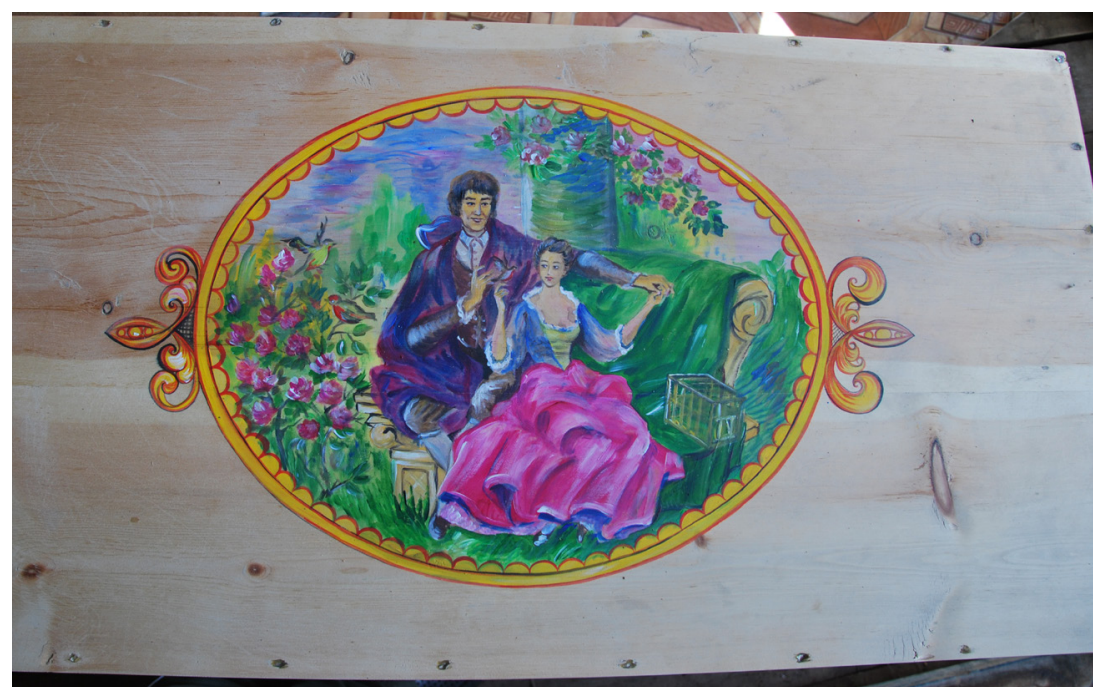

Фото 8. Свадебный сундук. Мастер И. Черепанов. Эржей, Каа-Хемский район. Фото А. Пригарина, 2016 г.

Photo 8. Wedding chest. Master I. Cherepanov. Erzhey, Kaa-Khem raion. Photo by A. Prigarin, 2016. 
их как геометрической резьбой, так и росписью. По свидетельству информантов, при заказе свадебного сундука пользуется спросом сюжетная роспись с изображением влюбленных пар (фото 8), а также лебедей, источником которых является книжная иллюстрация и открытки.

Еще одно проявление массовой культуры - распространение любительской фотографии, которая декларативно запрещена в старообрядческой среде, но нарушается повсеместно. Как показывают материалы экспедиций 60-х годов XX и современные исследования: фотоальбомы и семейные хроники продолжают собираться и имеют историю в 50-60 лет. В своих дневниках в 1967 г. Н. Н. Покровский отмечал, что в Ужепе в доме Миковых «много фотографий и фотоаппарат “Смена”, купленный Костей из собственного заработка. Есть фотографии родителей. Есть фото родителей 20-летней давности» (Урало-Сибирский патерик, 2016: 155). В полевых исследованиях последних лет в старообрядческих домах достаточно часто встречаются фотоальбомы, отражающие повседневную жизнь человека с 1960-х годов до сегодняшнего дня. Необходимо сделать уточнение, что о существовании семейных фотографий информанты сообщают неохотно, особенно представители пожилого населения, тем не менее, при общении с людьми среднего возраста (30-50 лет) выясняется, что подобные альбомы есть в каждой второй семье старообрядческих поселений Каа-Хемского района Республики Тыва. Как подтверждают современные полевые исследования, несмотря на конфессиональные запреты, в старообрядческих семьях бережно хранят семейные фотографии и продолжают создавать семейные фотохроники, запечатлевая наиболее яркие события в жизни: школьные годы, свадьбы, встречи с близкими родственниками и т. д. В современных условиях староверы делают фотографии сами и позволяли нам в экспедициях делать фотографии, даже вместе с ними, но с оговоркой не размещать в Интернете. Как показали полевые исследования 2016-2018 гг. в староверческой среде на малом Енисее к фотографированию относятся с терпимостью; в беседах негативная оценка фотографии давалась пожилыми (после 70 лет) соборными староверами.

Таким образом, визуальный мир повседневности староверов Енисея достаточно эклектичен и не однозначен в своей оценке приверженности к традициям и устойчивому влиянию массовой культуры в современном мире, что разрушает общественные стереотипы о консервативности данного конфессионального сообщества.

\section{Заключение}

Исходя из вышеизложенного следует констатировать, что визуальные образы современных старообрядцев продолжают сохранять традиционные иконографические устои, что находит свое отражение в бережном отношении к культовым предметам: книгам, иконам, четко декларирующими конфессиональные маркеры принятия и отторжения чужих традиций. Визуальные образы, созданные в результате конструирования или компиляции, эмоционально окрашиваются, вступая в ассоциативную связь с определенными ценностями, событиями и идеями, значимыми в старообрядческой среде. Глубина внутреннего содержания, сложность и многогранность этих идей составляет основу зрительного образа в иконе, книге, народной картинке и других предметах, используемых в конфессиональных целях. Согласно сложившимся стереотипам, образ жизни старообрядцев в большинстве своем связан с их прочным сопротивлением разного рода нововведениям, их мировоззрение представляется как замкнутое и закрытое для научно-технического прогресса и массовой культуры.

Современные народные картинки, найденные у старообрядцев на Енисее, уникальный источник нарратива, является посредником между доктринальными конфессиональными установками и повседневностью. Визуальный образ старообрядческой народной картинки, как канал распространения информации о современном мире, является конфессиональным оценочным взглядом с эсхатологическими мировоззренческими установками. 
Но, как показал анализ экспедиционных материалов, современная предметно-пространственная среда, которая формирует визуальный мир старообрядцев-часовенных Тувы, открыта новациям. Изучение культуры старообрядцев в живом, реально пространственно-временном контексте позволяет увидеть сближение традиций и новаций, их трансформация переводит их на другой понятийно-образный уровень, о чем свидетельствуют современные лубочные картины, созданные на Енисее и предметно-пространственная среда повседневного мира. Трансформация традиционной культуры под влиянием массовой неизбежный процесс в закрытых общинах и ведет к модификации жизненного пространства и «послаблению» в использовании благ цивилизации.

\section{СПИСОК ЛИТЕРАТУРЫ}

Бубнов, Н. Ю. (1995) Старообрядческая книга в России во второй половине XVII в. Источники, типы и эволюция. СПб. : БАН. 435 с.

Быкова, Е. В., Костров, А. В. (2018а) «Широкий путь» в сознании старообрядцев Енисея: современная народная картинка о процессах глобализации // Традиционная культура. Т. 20. № 2. C. 62-76.

Быкова, Е. В., Костров, А. В. (2018b) «Игра пространства» в современном старообрядческом лубке // Научные труды. Проблемы развития отечественного искусства. № 44. С. 174-185.

Духовная литература староверов Востока России XVIII-XX вв. (1999) : в 3-х т. / под ред. Н. Н. Покровского. Новосибирск : Сибирский хронограф. Т. 1. 800 с.

Зольникова, Н. Д. (2018) Полевой дневник археографической группы Н. Н. Покровского (Тува, 6-7 августа 1967 г.) // Известия Иркутского государственного университета. Серия «История». Т. 23. С. 152-157.

Зольникова, Н. Д. (2008) Полемика староверов часовенного согласия в начале XXI в.: крестное знамение и иконопись (статья первая) // Общественное сознание и литература России: источники и исследования / отв. ред. Н. Н. Покровский. Новосибирск : СО РАН. 414 с. С. 331-413.

Зольникова, Н. Д. (2009) Полемика староверов часовенного согласия в начале XXI в.: крестное знамение и иконопись (статья вторая) // Археографические исследования отечественной истории: текст источника в литературных и общественных связях / отв. ред. А. Х. Элерт, Н. Н. Покровский. Новосибирск : СО РАН. 358 с. С. 226-311.

Казанцева, Т. Г. (2017) Певческие книги в старообрядческих общинных библиотеках: репертуар и литургические функции // Библиотека традиционная и электронная: смыслы и ценности. Материалы межрегиональной научно-практической конференции : в 2 т. / отв. ред. Е. Б. Артемьева, О. Л. Лаврик. Новосибирск : СО РАН. Т. 2. 353. С. 132-140.

Керов, В. В. (2016) «Се человек и дело его...»: Конфессионально-этические факторы старообрядческого предпринимательства в России. М.: Изд-во» Экон-Информ», 2016. - 590 с.

Любимова, Г. В. (2004) Старообрядцы-часовенные верховьев Малого Енисея: традиции и новации // Проблемы межэтнического взаимодействия в Сибири / отв. ред И. Н. Гемуев. Новосибирск : Арт Инфо Дата. Вып. 2.112 с. С. 50-64.

Любимова, Г. В. (2009) «Техническая эсхатология» в современной народно-православной и старообрядческой традиции Сибири // Археология, этнография и антропология Евразии. № 3 (39). С. 119-127.

Моррис, Ч.У. (1983) Основание теории знаков // Семиотика : сб. статей : переводы под общ. ред. Ю. С. Степанова. М. : Радуга. 636 с. С. 37-89.

Покровский, Н. Н., Зольникова, Н. Д. (2002) Староверы-часовенные на Востоке России в XVIII-XX вв. Проблемы творчества и общественного сознания. М. : РАН. 471 с. 
Стороженко, А. А. (2016) Орнаментика старообрядческих крестьянских рукописей верхнего Енисея (по экспедиционным материалам в Республике Тува) // Орнаментика в артефактах традиционных культур. Материалы Пятнадцатых Международных Санкт-Петербургских этнографических чтений / отв. ред. В. М. Грусман, Е. Е. Герасименко. СПб. : Санкт-Петербургский университет технологии и дизайна. 412 с. С. 31-33.

Стороженко, А. А. (2015) Конфессиональные миграции старообрядцев как канал межкультурного взаимодействия в Центральной Азии в XIX - начале XX в. // Старообрядчество: история и современность, местные традиции, русские и зарубежные связи: Материалы VI Международной научно-практической конференции / отв. ред. С. В. Васильева. Улан-Удэ : Бурятский государственный университет. 392 с. С. 130-136.

Татаринцева, М. П. (2006) Старообрядцы в Туве. Историко-этнографический очерк. Новосибирск : Наука. 216 с.

Урало-Сибирский патерик: тексты и комментарии (2016): в 3 т. / подгот. Н. Н. Покровский, Н. Д. Зольникова, О. Д. Журавель. М. : ЯСК. Т. 3, кн. 2. 296 с.

Дата поступления: 15.10.2018 2.

\section{REFERENCES}

Bubnov, N. Iu. (1995) Staroobriadcheskaia kniga v Rossii vo vtoroi polovine XVII v. Istochniki, tipy $i$ evoliutsiia [Old Belief books in Russia in the second half of the 17th century: sources, types and evolution]. St. Petersburg, BAN. 435 p.

Bykova, E. V. and Kostrov, A. V. (2018a) «Shirokii put'» v soznanii staroobriadtsev Eniseia: sovremennaia narodnaia kartinka o protsessakh globalizatsii [The "broad way" in the consciousness of the Yenisei old believers: a contemporary folk picture of the processes of globalization]. Traditsionnaia kul'tura, vol. 20, no. 2, pp. 53-63. (In Russ.).

Bykova, E.V. and Kostrov, A. V. (2018 b) «Igra prostranstva» v sovremennom staroobriadcheskom lubke ["Play with Space” in modern old believers' lubok]. Scientific Papers, no. 44, pp. 174-185. (In Russ.).

Dukhovnaia literatura staroverov Vostoka Rossii XVIII-XX vv. [Spiritual Literature by Old Believers of Russian East in 18th - 19th cent.] (1999). Ed. by N. N. Pokrovskii. Novosibirsk, Sibirskii khronograf. Vol. 1.800 p. (In Russ.).

Zol'nikova, N. D. (2008) Polemika staroverov chasovennogo soglasiia v nachale XXI v.: krestnoe znamenie i ikonopis' (stat'ia pervaia) [Polemics of Chasovennye Old Believers at the beginning of 21st: sign of the Cross and icon-painting (Part 1)]. In: Obshchestvennoe soznanie $i$ literatura Rossii: istochniki $i$ issledovaniia [Public conscience and Russian literature: sources and research]. Ed. by N. N. Pokrovskii. Novosibirsk, SO RAN. 414 p. Pp. 331-413 (In Russ.).

Zol'nikova, N. D. (2009) Polemika staroverov chasovennogo soglasiia v nachale XXI v.: krestnoe znamenie i ikonopis' (stat'ia vtoraia) [Polemics of Chasovennye Old Believers at the beginning of 21st century: sign of the Cross and icon-painting (Part 2)]. In: Arkheograficheskie issledovaniia otechestvennoi istorii: tekst istochnika $v$ literaturnykh i obshchestvennykh sviaziakh [Text of a source in literature and social environment]. Ed. by A. H. Elert and N. N. Pokrovskii. Novosibirsk, SO RAN. 358 p. Pp. 226-311. (In Russ.).

Zol'nikova, N. D. (2018) Polevoj dnevnik arheograficheskoj gruppy N. N. Pokrovskogo (Tuva, 6-7 avgusta 1967 g.) [The Field Journal of N. N. Pokrovskiy"s Archeographic Research Group (Tuva, August, 6-7, 1967)]. Izvestija Irkutskogo gosudarstvennogo universiteta. Serija «Istorija», vol. 23, pp. 152-157. (In Russ.).

Kazantseva, T. G. (2017) Pevcheskie knigi v staroobriadcheskikh obshchinnykh bibliotekakh: repertuar i liturgicheskie funktsii [Singing books in Old Believers ' community libraries: repertoire 
and liturgical functions]. In: Biblioteka traditsionnaia i elektronnaia: smysly i tsennosti [Traditional and electronic libraries: meanings and values.]. Materials of interregional research conference. Novosibirsk, SO RAN. Vol. 2. 353 p. Pp. 132-140. (In Russ.).

Kerov, V.V. (2016) «Se chelovek i delo ego...»: Konfessional'no-eticheskie faktory staroobriadcheskogo predprinimatel'stva v Rossii ["This is a man and his work ...": Confessional and ethical factors of Old Believer entrepreneurship in Russia]. Moscow, Ekon-Inform, 590 p. (In Russ.).

Liubimova, G. V. (2004) Staroobriadtsy-chasovennye verkhov'ev Malogo Eniseia: traditsii i novatsii [Chasovennye Old Believers of the upper Small Yenisei: traditions and innovations]. In: Problemy mezhetnicheskogo vzaimodeistviia v Sibiri [Problems of interethnic cooperation in Siberia] / ed. by I. N. Gemuev. Novosibirsk, ArtInfoData. Vol. 2. 112 p. Pp. 50-64. (In Russ.).

Liubimova, G. V. (2009) «Tekhnicheskaia eskhatologiia» v sovremennoi narodno-pravoslavnoi i staroobriadcheskoi traditsii Sibiri ["Technological eschatology" in contemporary traditions of popular Orthodoxy and among the Old Believers of Siberia]. Archaeology, Ethnology and Anthropology of Eurasia, no. 3 (39), pp. 119-127 (In Russ.).

Morris, Ch. W. (1983) Osnovanie teorii znakov [Foundations of the theory of signs]. In: Semiotics. Digest of articles. Translations. Ed. by Yu. S. Stepanov. Moscow, Raduga. 636 p. Pp. 37-89 (In Russ.).

Pokrovskii, N. N. and Zol'nikova, N.D. (2002) Starovery-chasovennye na Vostoke Rossii v XVIII-XX vv. [Chasovennye Old Believers in the East of Russia in 18th -20th centuries]. Moscow, RAN. 471 p. (In Russ.).

Storozhenko, A.A. (2015) Konfessional'nye migratsii staroobriadtsev kak kanal mezhkul'turnogo vzaimodeistviia v Tsentral'noi Azii v XIX - nachale XX v. [Confessional migration of Old Believers as a channel of intercultural interaction in 19th - early 20th century Central Asia]. In: Staroobriadchestvo: istoriia i sovremennost', mestnye traditsii, russkie i zarubezhnye sviazi [Old Believers: history and modernity, local traditions, Russian and foreign relations]. Materials of the VI International Scientific Practical Conference. Ed. by S. V. Vasilyeva. Ulan-Ude, Buriatskii gosudarstvennyi universitet. 392 p. Pp. 130-136. (In Russ.).

Storozhenko, A. A. (2016) Ornamentika staroobriadcheskikh krest'ianskikh rukopisei verkhnego Eniseia (po ekspeditsionnym materialamv Respublike Tuva) [Ornamentation of Old Believers' peasant manuscripts of the upper Yenisei: from the materials of expeditions to the Republic of Tuva)]. In: Ornamentika $v$ artefaktakh traditsionnykh kul'tur [Ornamentation in artifacts of traditional cultures.]. Materials of the Fifteenth International St. Petersburg Ethnographic Readings. Ed. by V. M. Grusman and E. E. Gerasimenko. St. Petersburg, Sankt-Peterburgskii universitet tekhnologii i dizaina. 412 p. Pp. 31-33. (In Russ.).

Tatarintseva, M. P. (2006) Staroobriadtsy v Tuve. Istoriko-etnograficheskii ocherk [The Old Believers in Tyva: A Historical and ethnographic essay]. Novosibirsk, Nauka. 216 p. (In Russ.).

Uralo-Sibirskij paterik: teksty i kommentarii [Ural-Siberian Patericon: texts and comments] (2016): in 3 vols. / prep. by N. N. Pokrovskii, N. D. Zol'nikova and O. D. Zhuravel'. Moscow, Publ. IaSK. Book 2, Vol. 3. 296 p. (In Russ.). 